\title{
DEPOSITION FROM THE CROSS AND OTHER POEMS
}

\author{
Allan Popa \\ Ateneo de Manila University \\ allanpopa@gmail.com
}

\section{About the Author}

Allan Popa is the author of ten collections of poetry, including Drone (Ateneo de Manila University Press, 2013) and Laan (De La Salle University Publishing House, 2013). He has received the Philippines Free Press Literary Award and the Manila Critics Circle National Book Award. He earned his MFA in Writing (Poetry) at Washington University in Saint Louis, where he won the Norma Lowry Prize and the Academy of American Poets Graduate Prize. He received fellowships to the New York State Writers Institute at Skidmore College from 2006 to 2011. He teaches at the Filipino Department of Ateneo de Manila University and is currently the Director of Ateneo Institute of Literary Arts and Practices (AILAP). He is pursuing doctoral studies at De La Salle University-Manila. 
DEPOSITION FROM THE CROSS

[After Vasari]

Hearing your name you turn upward to the one carefully commending to your hands this body

whose weight in your arms you must

commend to those below you or else the rung will

give from what you must bear yet you cannot move cannot turn toward the pit you cannot see the end of

as hearing your name you turn upward to the one commending to your hands this pendent body. 
ONE BY ONE, OUR BODIES ARE RELEASED BY CRISIS

When I accepted the money agreed upon

I had to assure myself: couldn't have

done it, couldn't have even imagined doing it.

What made you do it?

He whispered in my ear

it became possible.

What made you do it again?

Against my palm he counted the price

of my every refusal; I felt his joy in my shame

until he reached the sum of my abandon.

What made you do it again?

I felt shame creeping on my skin; shame

that had become possible to take off

put on take off put on until the threads wore away.

What made you do it again?

In my mind I heard a distant song that consoles me even now as I wipe the dirt smeared on my face. 


\section{REAL ESTATE}

My mother believes she holds

the night hostage inside a bottle.

She picks the label like a scab.

Inside her night, my brother,

halfway through the rosary,

slurs the Gloria Patri.

His suitcase brims with brochures.

How to tuck him into the glossy folds.

We are all past shelf lives.

He says ropes are raining

from the ceiling. He wants to be

tied to the house he can't help but leave.

I am left knotting ends to stop

the unraveling. My face

lit with late news.

In a dream I ask for directions.

The dream is wrong. Even in sleep

I am home waiting. 
If the string doesn't break

If the prayers stir

If I stay

My brother's hand inside

the living room couch gropes for a pill,

a bead among the mysteries. 
WAY OF THE CROSS (For Francisco "Kokoy" Guevarra)

1.

With no money in our pockets, with nothing to hold, we come in droves barefoot. Months without rain, we flood the streets dry-blood red.

We are walking through the night, through the ink of news, we are walking through red lights, awake with purpose. We know our way, we'll meet you there, we are the city, we are not the news.

Red with the flag, red with the sword, red with the sea you parted, the sea you crossed, red with the shipboard blaze, red with your robe, your scarlet robe, we walk. 
2.

Where the private goes public, we part to give way: flagellants marching to their own whipping, their backs crossed out.

With faces hooded, they cut a path by spraying blood to our averting eyes. Blind on their way, the penitents are led by the lashing sound of the one marching ahead: thorny twigs wound crown obedience.

When we shut our eyes, dangerous to mistake this lashing music for the soothing rattle of wind chimes, so we stare, unblinking.

How long shall we stare by the side of the road before we recognize the wounds they bear are not our own? 
3 .

We wave our white linens along your way. We are sweat, we are tears, we are piss, we are a sea of men, we are blood. We stir the dust, we wet the streets, we muddle the mud, we cling to grime as grime clings to us. We are dirt. 
4.

We soil and cleanse ourselves with each other's namelessness.

Against the wave of bodies mounting bodies straining to touch your hem, against the longing to be stained, against the weight of your carriage, against the weight of your fall under the weight of the cross, we suffer our selves to pull you past.

Moving through our bodies (standing in the way to make way) is a procession. 